\title{
G cell population of the gastric antrum, plasma gastrin, and gastric acid secretion in patients with and without duodenal ulcer
}

\author{
C. M. S. ROYSTON ${ }^{1}$, JULIA POLAK, S. R. BLOOM, W. M. COOKE ${ }^{2}$, \\ R. C. G. RUSSELl ${ }^{3}, A$. G. E. PEARSE, J. SPENCER, R. B. WELbOURN, AND \\ J. H. BARON 4 \\ From the Departments of Surgery, Histochemistry, and Medicine, Royal Postgraduate Medical School, \\ London
}

SUMMARY Estimates of the $G$ cell population were made in 24 resected human pyloric antra from counts of cells in multiple samples and from measurements of antral size. Measurements had been made previously in 20 subjects of acid output (basal and after pentagastrin) and in 10 subjects of plasma gastrin (basal and after insulin + bicarbonate). G cells were most dense near the pylorus, but their circumferential distribution was even. The $\mathrm{G}$ cell populations ranged from 8 to 15 (mean 10) million in four control patients and from 3 to 43 (mean 18) million in 15 patients with duodenal ulcer. Those with recurrent ulcer after vagotomy had either a low $\mathbf{G}$ cell count and incomplete vagotomy, or a high $\mathbf{G}$ cell count and apparently complete denervation. Two patients with hypergastrinaemia and duodenal ulcer had moderate $\left(29 \times 10^{6}\right)$ or marked $\left(56 \times 10^{6}\right)$ excesses of $\mathrm{G}$ cells. ' $G$ cell hyperplasia' may represent the extreme end of the normal range of $G$ cell numbers in the antrum, and can be assessed by semi-quantitative grading of $\mathrm{G}$ cell hyperplasia in antral biopsies. There were significant direct correlations between antral area and $G$ cell density, between peak acid output and $\mathrm{G}$ cell population, and between basal plasma gastrin and $\mathrm{G}$ cell density (but not population). We suggest that, in patients with duodenal ulcer, acid and gastrin secretion are interrelated and that both are related to the masses of parietal cells and of $\mathrm{G}$ cells.

In 1967 Solcia and his colleagues described some endocrine-like cells in the gastric antrum which were argyrophilic, but non-argentaffin, in quality. The next year McGuigan (1968), by means of an immunofluorescent technique, identified gastrin in cells of the antral mucosa, which he named G cells. In 1970 Bussolati and Pearse, by using immunofluorescent and silver techniques, found that these two types of cell were the same.

$G$ cells have been studied in various diseases and found to be present in increased density in pernicious anaemia (Rubin 1969; Creutzfeldt et al., 1971; Polak et al., 1971), acromegaly (Creutzfeldt et al., 1971),

\footnotetext{
${ }^{1}$ Present address: Royal Infirmary, Hull.

2Present address: Middlesbrough General Hospital.

${ }^{3}$ Present address: Middlesex Hospital, London.

${ }^{4}$ Address for correspondence: Dr J. H. Baron, Department of Surgery, Royal Postgraduate Medical School, Hammersmith Hospital, London, W12 0HS.

Received for publication 3 February 1978
}

and hyperparathyroidism (Creutzfeldt et al., 1971; Polak et al., 1971), but not in duodenal ulcer disease (Creutzfeldt et al., 1976). Marked antral G cell hyperplasia has been found in one patient with hypergastrinaemia without gastrinoma (Cowley et al., 1973b). Recently it has been suggested, from comparison of basal and insulin-bicarbonate stimulated plasma gastrin, that patients with duodenal ulcer have an increased functional $\mathrm{G}$ cell mass (Cowley et al., 1973a). Similarly, it has been suggested that patients with duodenal ulcer may be divided into two types, one having an increase in antral $\mathrm{G}$ cells (Solcia et al., 1970; Polak et al., 1972) the other having normal numbers of G cell (Ganguli et al., 1974).

All these morphological studies have been concerned with $G$ cell density - that is, the number of $G$ cells per unit area-in biopsies and provide no information on the total number of $G$ cells in the stomach. We have therefore developed a method for estimating the $\mathrm{G}$ cell population of the stomach and have used it in patients with different diseases. We 689 
have also correlated the estimated populations with measurements of basal and peak acid output, and of basal and stimulated plasma gastrin.

\section{Methods}

PATIENTS STUdied

The antra of 31 patients were studied. Those with duodenal ulcer were a consecutive series undergoing vagotomy and antrectomy. Seven studies were unsuccessful because of severe antral gastritis (see below). Of the 24 antra studied successfully, 15 were from patients with chronic duodenal ulcers, one from a patient with combined gastric and duodenal ulcer, and two from patients with recurrent duodenal ulcers. In one of these two patients the ulcer had recurred 18 months after truncal vagotomy and pyloroplasty, and a large posterior vagal trunk was found at reoperation; the other patient had had persistent pain after selective vagotomy and pyloroplasty, and at reoperation had a large duodenal ulcer but no obvious vagal fibres.

Two patients with gastric hypersecretion, hypergastrinaemia, and duodenal ulcer who were suspected of having Zollinger-Ellison syndrome were studied. The first patient had a mean preoperative plasma gastrin of $532 \mathrm{pmol} / \mathrm{l}$ (normal < 50) and, although no abnormality was found in the pancreas, she was treated by total gastrectomy. Her mean postoperative plasma gastrin was $77 \mathrm{pmol} / \mathrm{l}$. The second patient, who had had vagotomy previously, had a mean plasma gastrin of $123 \mathrm{pmol} / \mathrm{l}$. No abnormality was found in his pancreas either, but he was treated by subtotal gastrectomy because the possibility of antral $\mathrm{G}$ cell hyperplasia was recognised. His postoperative plasma gastrin was $34 \mathrm{pmol} / 1$.

It was clearly impossible to obtain antra from patients with normal stomachs, and the control subjects had had Whipple's operations performed for carcinoma of the ampulla of Vater or pancreas. Three of these patients were deeply jaundiced with obstructed pancreatic ducts at the time of operation. Although they were not ideal controls, their gastric mucosae appeared normal histologically. The fourth patient had a two stage procedure, a local resection of the carcinoma followed by Whipple's operation when the jaundice had resolved. In this patient acid secretion (BAO 0.01, PAO $_{\mathrm{pg}} 8.9 \mathrm{mmol} / \mathrm{h}$ ) and gastrin levels (basal 4, rise $18 \mathrm{pmol} / \mathrm{l}$ ) measured before the second operation suggested that his stomach was healthy.

PREOPERATIVE INVESTIGATIONS

The acid and gastrin studies were performed at least 48 hours before operation.

\section{Gastric acid secretion}

This was measured after an overnight fast. A nasogastric tube was inserted and its position checked by fluoroscopy. The stomach was emptied and the basal acid output (BAO) was measured by continuous collection of the gastric secretion for one hour. Pentagastrin, $6 \mu \mathrm{g} / \mathrm{kg}$, was injected intramuscularly and four further 15 minute samples were collected. Peak acid output (PAO) was calculated by doubling the sum of the two highest consecutive 15 minute samples. Both BAO and PAO were expressed as $\mathrm{mmol} / \mathrm{h}$. All but one of the patients with an ulcer, but only one of the control subjects, had these preoperative acid tests.

\section{Plasma gastrin levels}

These were determined by a radioimmunoassay technique (Russell et al., 1976) which specifically measures physiologically active gastrin, both G-17 and G-34. Gastrin concentrations are expressed as pmol/1 G-17 equivalents. Stimulated gastrin release was measured by an insulin-bicarbonate test (Cowley et al., 1973a). After an overnight fast insulin (0.2 units $/ \mathrm{kg}$ ) was injected intravenously and the patient then drank quickly $50 \mathrm{ml}$ bicarbonate solution (500 mmol/l). He sipped the same solution continuously ( $25 \mathrm{ml} / 15 \mathrm{~min})$ throughout the test. Blood samples were taken for measurement of glucose and gastrin at $-5,0,15,30,45,60$, and 75 minutes. Gastrin 1 measured in seven of the patients with duodenal ulcer, both patients with hypergastrinaemia, and in one of the control subjects.

\section{G CELL POPULATIONS}

$G$ cell populations were counted by techniques derived from earlier work on the counting of parietal cells, in which measurements were made both of the surface area of the antrum and of the number of parietal cells per unit area (Cox and Barnes, 1945; Card and Marks, 1960; Reid et al , 1961).

Each antrum removed at operation was immediately cut open along the greater curve. The mucosa was dissected from the muscle and pinned out onto a cork board to ensure that the mucosa was fully stretched and that no wrinkles were present (Fig. 1). The board and mucosa were immersed in methanol free formalin for 24 hours. This fixative was changed to sucrose buffer solution (Polak et al., 1971). The fixed antrum was placed on a piece of cardboard, onto which its outline was drawn (Fig. 1). Three strips of mucosa were cut from the pylorus to the junction of the antrum and body, one each from the lesser curve, the anterior surface, and the posterior surface. The positions of these strips were marked on the cardboard. Each was divided into carefully measured smaller strips, 15 to $20 \mathrm{~mm}$ long, which 


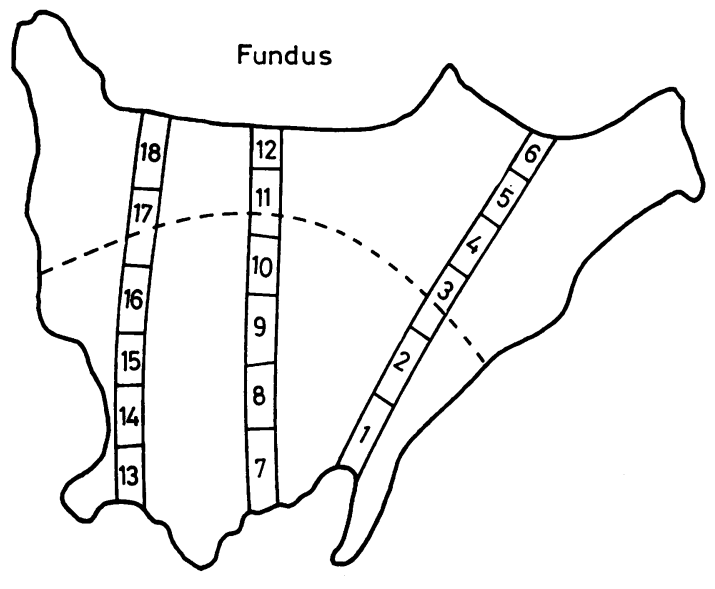

Pylorus

Fig. 1 The outline of the antrum of the stomach has been drawn on a piece of cardboard. The three main strips are shown, and the smaller numbered sections of the three strips are marked. The dotted line represents the junction between antrum and body of stomach determined histologically (see text).

were then dehydrated and embedded in wax. Two series of sections $5 \mu \mathrm{m}$ thick were cut. One series was stained with haematoxylin and eosin, the other treated to demonstrate the $G$ cells. The sections stained with haematoxylin and eosin were examined histologically to identify the junction between the antrum and the body of the stomach. The antrumbody junction in each of the three strips was marked onto the cardboard plan of the stomach. The outline of the antrum was thus determined and its surface area measured with a planimeter. The haematoxylin and eosin sections were studied by two of us and the severity of the gastritis assessed.

The remaining sections were stained for $\mathrm{G}$ cells by means of the indirect immunofluorescent technique (Coons et al., 1955). The first layer was rabbit antihuman gastrin I serum (Polak et al., 1973) and the second fluorescein-labelled goat anti-rabbit IgG globulin. The sections were mounted and counted under direct vision, by means of an immunofluorescent microscope. G cells were counted only in sections cut vertically to the mucosal surface. An uncorrected count of $\mathbf{G}$ cells was thus obtained. Corrections were made for shrinkage during the process of dehydration and for cellular overestimation.

Corrections for shrinkage were calculated from measurements of each small strip both before and after dehydration. The first measurement was made with the naked eye with a ruler and the second under the microscope with an eyepiece micrometer. When the shrinkage of each section had been measured, that of the area of the whole antrum was calculated.

Each section was $5 \mu \mathrm{m}$ thick and the average measured diameter of the $\mathrm{G}$ cells was $17 \mu \mathrm{m}$. Each section therefore contained cells which lay partly in adjacent sections. To correct for over-estimation of cells, Abercrombie's (1946) formula for nuclear overestimation was modified:

$\begin{aligned} & \text { Corrected } \\ & \text { count }\end{aligned}=\frac{\text { Uncorrected count } \times \text { thickness of section }}{\text { Mean diameter of G cell }+ \text { thickness of section }}$

The $\mathrm{G}$ cell population was then calculated from the formula:

$\mathrm{G}$ cell populatiun $=\frac{\begin{array}{c}\text { Corrected Surface Area } \times \text { Corrected } \\ \text { count per unit area }\end{array}}{\text { Thickness of section }}$

It was difficult to count $G$ cells accurately and reproducibly. Photographic techniques were tried initially, but abandoned. Eventually the cells were counted directly in small strips under an immunofluorescent microscope. When, as was usual, the cells lay in clumps, they were counted by eye in the whole field. When there was marked hyperplasia, a graticule was used to increase accuracy.

Duplicate $\mathbf{G}$ cell counts were made in three antra (Table 1). First they were counted by one observer on two separate occasions at least one week apart. Secondly they were counted by two different observers independently. The result revealed acceptable reproducibility within and between observers.

Finally, in one antrum, two sections were taken from each of 57 strips and each section was counted. The coefficient of variation between pairs of sections ranged from 0.5 to $46 \%$ (mean $12 \cdot 6$ ).

Table 1 Duplicate counts of $G$ cells in three antra

\begin{tabular}{|c|c|c|c|c|}
\hline & \multicolumn{3}{|c|}{$G$ cells $\left(\times 10^{\circ}\right)$ in antra } & \multirow{2}{*}{$\begin{array}{l}\text { Mean } \% \\
\text { difference }\end{array}$} \\
\hline & 1 & 2 & 3 & \\
\hline $\begin{array}{c}\text { Observer A 1st count } \\
\text { Observer A 2ndcount } \\
\overline{\text { X }} \\
\text { Difference } \\
\text { from } \bar{x} \\
\% \\
\text { Observer A } \\
\text { Observer B } \\
\overline{\mathbf{x}} \\
\text { Difference } \\
\text { from } \bar{x} \\
\%\end{array}$ & $\begin{array}{l}17 \cdot 9 \\
19 \cdot 2 \\
18 \cdot 55 \\
\\
0 \cdot 65 \\
3 \cdot 5 \\
17 \cdot 9 \\
16 \cdot 8 \\
17 \cdot 35 \\
\\
0 \cdot 55 \\
3 \cdot 2\end{array}$ & $\begin{array}{l}27 \cdot 4 \\
26 \cdot 1 \\
26 \cdot 75 \\
\\
0 \cdot 65 \\
2 \cdot 4 \\
27 \cdot 4 \\
28 \cdot 3 \\
27 \cdot 85 \\
\\
0 \cdot 45 \\
1 \cdot 6\end{array}$ & $\begin{array}{l}2 \cdot 4 \\
2 \cdot 1 \\
2 \cdot 25 \\
\\
0 \cdot 15 \\
6 \cdot 7 \\
2 \cdot 4 \\
1 \cdot 9 \\
2 \cdot 15 \\
0 \cdot 25 \\
11 \cdot 6\end{array}$ & $4 \cdot 2$ \\
\hline
\end{tabular}

ESTIMATION OF DEGREE OF HYPERPLASIA In order to determine whether or not a subjective assessment of the density of $G$ cells in random samples of antra correlated with the total $\mathbf{G}$ cell populations, sections of each antrum were examined by one of us and graded as normal (grade 0) or as showing hyperplasia, grades 1,2 , or 3 . The normal distribution of $\mathrm{G}$ cells (Fig. 2a) has been established 
in biopsies from healthy stomachs and shows a few scattered G cells, with only one or two around each gland. Grade 1 hyperplasia indicates that a band of $G$ cells is present in the midmucosal zone but with gaps in the band. In grade 2 hyperplasia (Fig. 2b) the band of $G$ cells is complete but still confined to the midzone of the mucosa, and in grade 3 hyperplasia (Fig. 2c) the band of cells is greatly extended towards the muscle and mucosal surfaces.

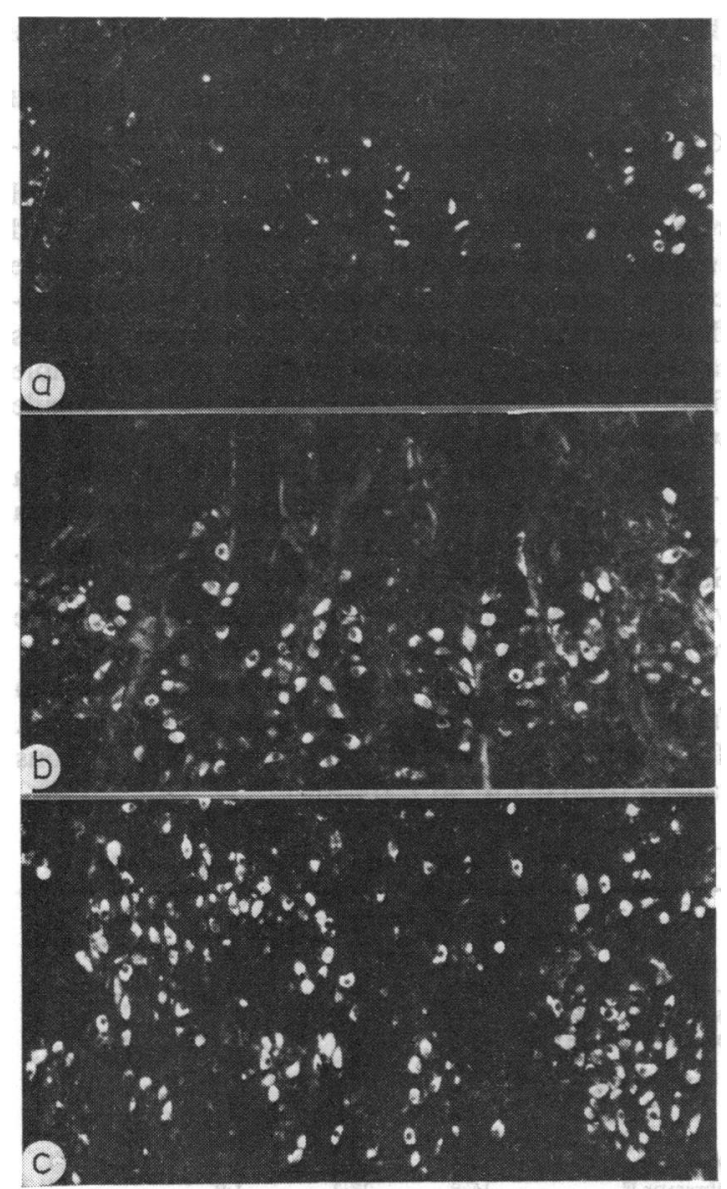

Fig. 2 Immunohistochemical staining of human antral mucosa, using antibodies to synthetic human gastrin I, illustrating the normal distribution and grades of hyperplasia. $(a),(b)$, and $(c)$ are cut vertically and identically. (a) The $G$ cells appear normal in number and distribution (grade 0 ). Note that $G$ cells are present exclusively in the mid-zone of the mucosa. (b) Moderate $G$ cell hyperplasia (grade 2). Some $G$ cells are seen in the lower third of the mucosa as well as in the mid-zone. (c) Severe $G$ cell hyperplasia-antral gastrinosis (grade 3). $G$ cells are seen in all areas of the mucosa, upper, middle, and lower thirds. ( $a, b, c$ : original magnification $\times 270$.)
STATISTICAL METHODS

Correlations were calculated as the correlation coefficient $r$ where the data were distributed normally, and by Spearman's rho when they were not. Basal acid output was normalised by logarithmic transformation.

\section{Results}

ANTRAL AREA (Fig. 3)

The areas of the antra ranged from 50 to $79 \mathrm{~cm}^{2}$ (mean 65 ) in control subjects, and from 40 to $110 \mathrm{~cm}^{2}$ (mean 73) in patients with duodenal ulcer. The areas in the patients with combined duodenal and gastric ulcer and hypergastrinaemia fell within the range of the other patients with duodenal ulcer. The antral area of one of the two patients with recurrent duodenal ulcer was greater than that of any of the other subjects.

G CELL DENSITY (Fig. 4)

The corrected $\mathrm{G}$ cell counts ranged from 6.5 to 13.6 cells/mm strip (mean 9.6) in control subjects and from 3.1 to 25.7 cells $/ \mathrm{mm}$ (mean 13.3 ) in patients with duodenal ulcer. The two patients with duodenal ulcer and hypergastrinaemia had counts of 26.2 and $39 \cdot 2$ cells $/ \mathrm{mm}$, outside the range of the other patients with duodenal ulcer.

ANTRAL AREA AND G CELL DENSITY

There was a significant correlation between the antral areas and the corrected $\mathrm{G}$ cell counts in the 15 patients with duodenal ulcer $(r=0.58, \mathrm{P}=0.02)$ but not in the whole group of 24 subjects $(r=0 \cdot 28, \mathrm{P}<0 \cdot 2)$.

G CELl POPULATIONS

The $\mathrm{G}$ cells were distributed evenly in 24 of the 31 antra studied. Seven stomachs (three duodenal ulcer, two recurrent duodenal ulcer, two gastric ulcer) had very patchy distributions which made estimation of total $G$ cell populations impossible, and each showed severe antral gastritis with metaplasia. They were therefore excluded from the analysis. In the 24 patients with an even distribution of $G$ cells, the degree of gastritis was mild or moderate, and usually involved small areas of the antrum only. The G cell populations of the four control patients were $7 \cdot 6,9 \cdot 4$, 10.0, and 14.7 (mean 10.4) million (Fig. 5). The mean $\mathrm{G}$ cell population in the 15 patients with duodenal ulcer was 18.2 million, and the range was very wide ( 2.5 to 42.8 million). One patient with combined duodenal and gastric ulcers had a G cell count of 10.0 million. The patient with a recurrent ulcer and a persisting vagal trunk had a low $G$ cell count $(5 \cdot 7$ million). The other patient with recurrent ulceration, in whom no vagal fibres were found at re-operation, had a high $G$ cell count ( $45 \cdot 8$ million). His BAO was 


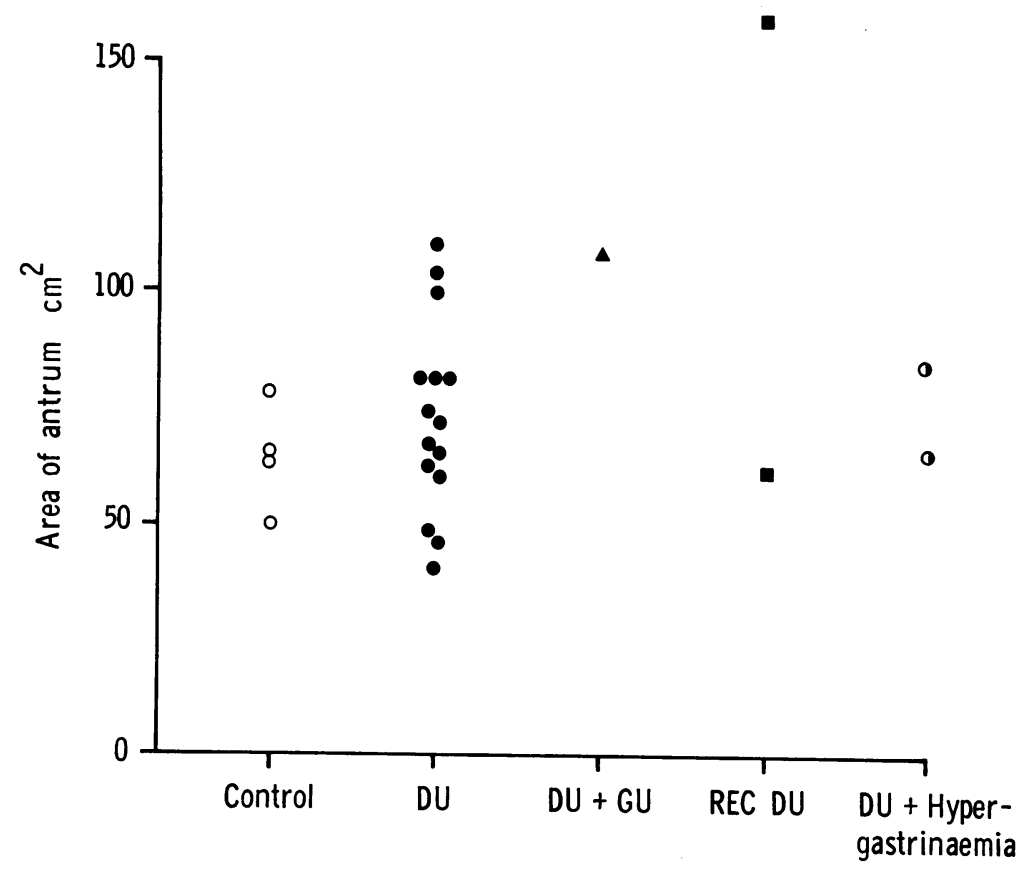

Fig. 3 Antral area in different clinical conditions: O control; $\bigcirc \mathrm{DU}$ (duodenal ulcer); $\triangle D U+$ $G U$ (duodenal and gastric ulcer); $\square E C D U$ (recurrent duodenal ulcer); (1) $D U+$ hypergastrinaemia (patients with duodenal ulcer and hypergastrinaemia-see text); the same symbols are used in Figs 4-6 also.

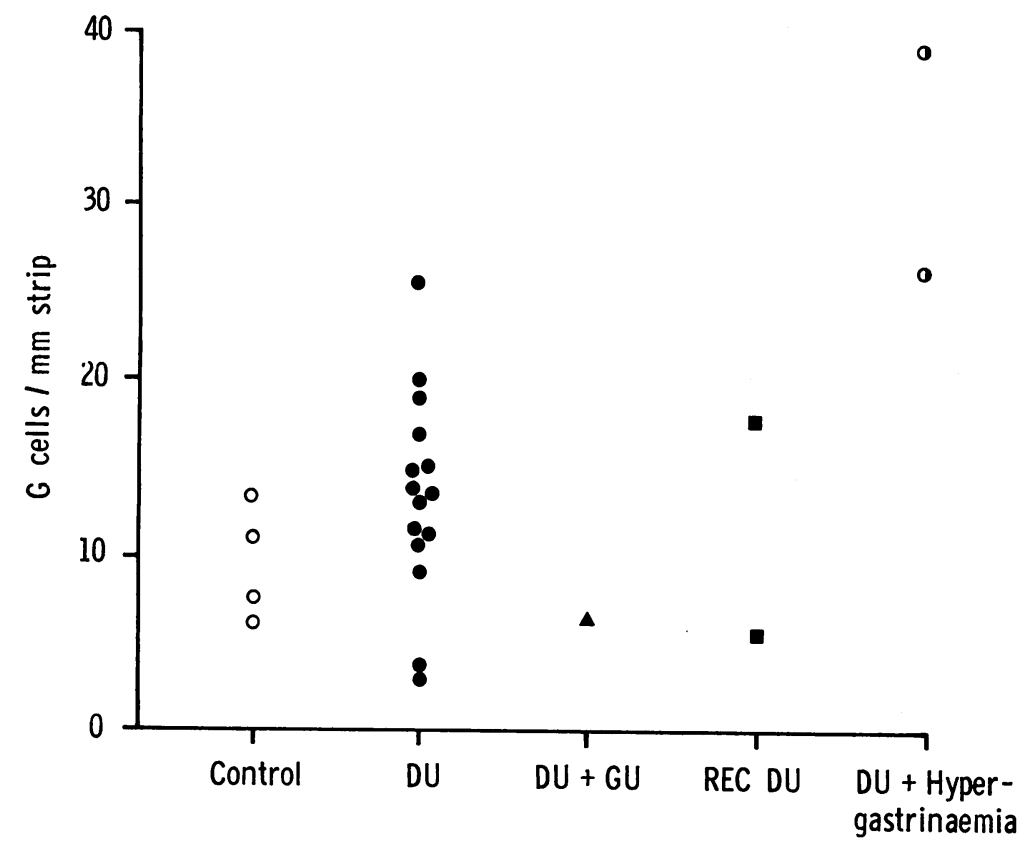

Fig. 4 G cell density in different clinical conditions.

$3.7 \mathrm{mmol} / \mathrm{h}$, and PAO $63.4 \mathrm{mmol} / \mathrm{h}$, but his fasting plasma gastrin was normal $(16 \mathrm{pmol} / \mathrm{l})$. Of the two patients with hypergastrinaemia and duodenal ulcer one had a moderate degree of $\mathrm{G}$ cell hyperplasia (28.7 million) but the other had very marked hyperplasia with the highest count recorded (56.1 million).

Thus the $\mathrm{G}$ cell populations in the different diagnostic groups showed a similar distribution to the corrected $\mathrm{G}$ cell counts. 


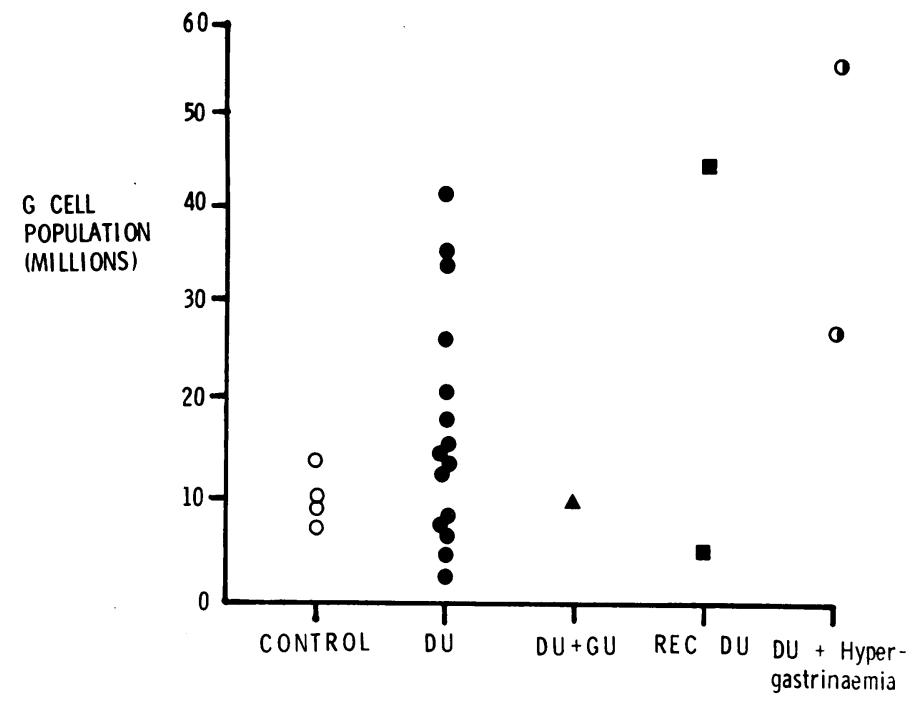

Fig. 5 G cell populations in different clinical conditions.
RELATIONSHIP BETWEEN G CELL

\section{POPULATION AND ACID SECRETION}

Peak acid output (PAO) was significantly correlated with $G$ cell population but the correlations between log basal acid output (BAO) and either G cell population or density were not significant at the $5 \%$ level (Table 2).

\section{RELATIONSHIP BETWEEN G CELL}

\section{POPULATION AND PLASMA GASTRIN}

Unfortunately, plasma gastrin was measured in only 10 subjects (one of four controls seven of 18 patients with duodenal ulcer, and in two patients with hypergastrinaemia) so that with these small numbers correlations are difficult to analyse and assess for significance. There was a significant correlation (rho $=0.56$ ) between basal plasma gastrin and $G$ cell density. The correlation between $\mathrm{G}$ cell population and basal plasma gastrin was minimally less (rho $=$ 0.52 ) and not significant at the conventional $5 \%$ level (Table 2). The correlations between $G$ cell population or density and peak or rise (peak minus basal) in gastrin levels were not significant, but there were only 10 observations.

CORRELATION BETWEEN G CELL POPULATION AND SUBJECTIVE VISUAL ESTIMATION OF HYPERPLASIA

Visual assessment was made of all the slides from which $\mathbf{G}$ cell counts were made. In most patients the whole antrum showed the same degree of hyperplasia. When variations were observed, the grade of hyperplasia covering the largest area was used for analysis. The actual $G$ cell density and the $G$ cell populations showed general correlations with the estimated grades of $\mathrm{G}$ cell hyperplasia (Fig. 6).

\section{DISTRIBUTION OF G CELLS}

The total number of $G$ cells in the whole of each of the three strips in each antrum was estimated and the mean $\mathrm{G}$ cell counts per $\mathrm{mm}$ in each strip were determined. These counts were similar (anterior 57.9, lesser curve 43.2 , posterior $45.8 \mathrm{G}$ cell $/ \mathrm{mm}$ ). The density of $G$ cells was highest near the pylorus, and fell off rapidly near the junction of the antrum and body (Fig. 7).

Table 2 Correlations of acid output and of plasma gastrin, with $G$ cell population and with $G$ cell density

\begin{tabular}{|c|c|c|c|c|c|c|c|c|c|}
\hline & \multirow[t]{2}{*}{$n$} & \multicolumn{4}{|c|}{ Correlation with $G$ cell population } & \multicolumn{4}{|c|}{ Correlation with corrected $G$ cell density } \\
\hline & & $\boldsymbol{r}$ & $\mathbf{P}$ & Rho & $\mathbf{P}$ & $\boldsymbol{r}$ & $\mathbf{P}$ & Rho & $\mathbf{P}$ \\
\hline $\begin{array}{l}\text { Log basal acid output } \\
\text { Peak acid output } \\
\text { Basal gastrin } \\
\text { Peak gastrin }\end{array}$ & $\begin{array}{l}20 \\
20 \\
10 \\
10\end{array}$ & 0.39 & $<0.09$ & $\begin{array}{l}0.41 \\
0.52 \\
0.4\end{array}$ & $\begin{array}{l}<0.05 \\
>0.05 \\
>0.05\end{array}$ & 0.40 & $<0.08$ & $\begin{array}{l}0.28 \\
0.56 \\
0.45\end{array}$ & $\begin{array}{l}>0.05 \\
<0.05 \\
>0.05\end{array}$ \\
\hline
\end{tabular}


Estimate of

$\mathrm{G}$ cell

hyperplasia

Grade 3

Fig. 6 Relationship between $G$ cell count and estimated degree of hyperplasia.

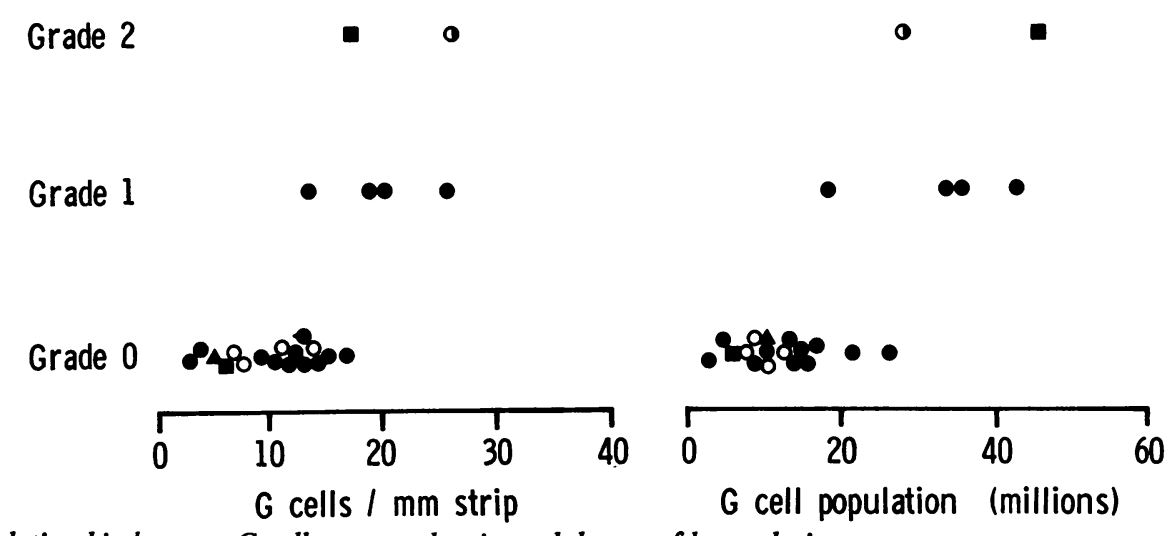

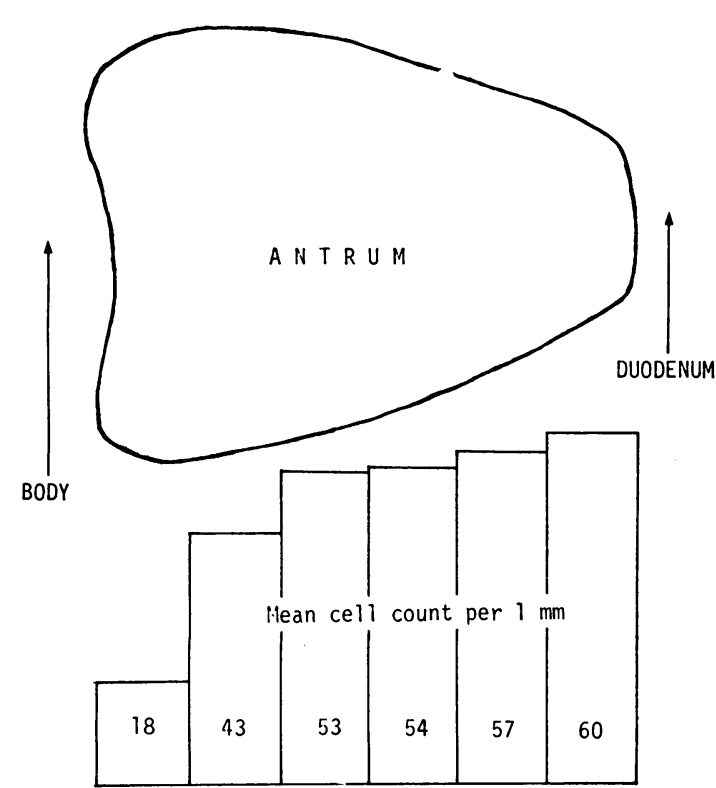

Fig. 7 Density of $G$ cells related to their position in the antrum.

\section{Discussion}

G CELl Counting

The accuracy of a $\mathbf{G}$ cell count depends most of all on the clarity of the immunofluorescence in the cells. Accuracy was high when the cells were full of gastrin. However, when gastrin was sparse, $G$ cell counting might have been inaccurate because of inadequate staining. Some gastrin may have leaked out of the $G$ cells during fixation, and if these $G$ cells were empty of gastrin they would not have been counted. The repeatability of our counts were satisfactory with intra- and inter- observer coefficients of variation of $4 \%$ and $5 \%$, which compare favourably with figures of $10 \%$ and $20 \%$ from Stave and Brandtzaeg (1976).

The accuracy of the estimation of $\mathrm{G}$ cell population depends on our assumption that the $G$ cells counted in the longitudinal antral strips were representative of the whole antrum. Making a similar assumption, Willems et al. (1976) have recently used transverse strips of stomach to estimate total gastrin cell numbers in rats. In our study results obtained from seven patients were discarded, because the uneven distribution of their $\mathbf{G}$ cells made accurate assessment of their number impossible. These antra showed 
evidence of severe destructive gastritis, whereas none of the other antra showed more than minor abnormalities. It appears that severe gastritis either damages the $\mathrm{G}$ cells, or makes them less easy to stain.

It has been impossible to establish the normal $G$ cell population as the control subjects were inevitably far from normal. However, there was much less variation around the mean (10 million) in our control subjects than there was in patients with duodenal ulcer. Biopsy studies in normal volunteers provide only $\mathrm{G}$ cell densities and not absolute counts. Post mortem studies are impracticable because the antra cannot be removed before digestive processes affect the $G$ cells.

\section{ANTRAL AREA}

In our patients with duodenal ulcer the mean area $\left(73 \mathrm{~cm}^{2}\right)$ of the antra defined histologically was double the mean antral area $\left(31 \mathrm{~cm}^{2}\right)$ defined as the alkaline zone in the $\mathrm{pH}$ studies of Capper et al. (1966). A similar discrepancy was noted by Hedenstedt et al. (1967).

\section{G CELL DISTRIBUTION}

There was an even circumferential distribution of $G$ cells in the three areas studied-namely, the lesser curve, and the anterior and posterior aspects of the antrum-whereas in the cat the $G$ cells were significantly denser on the lesser curve (Cowley et al., 1975). We have, however, found the highest density of $G$ cells near the pylorus (Fig. 7), the number gradually decreasing until the junctional zone between antrum and body is reached, where there is a marked decrease in numbers. We have not been able to find $G$ cells in the fundi of patients with duodenal ulcer. These results are similar to those of Stave and Bradtzaeg (1976).

\section{G CELL DENSITY AND POPULATION IN THE} ANTRUM

We have described previously varying grades of $G$ cell density based on subjective visual histochemical assessment (Ganguli et al., 1974). Our total G cell counts in the present study showed a reasonable general correlation with these estimated grades of $G$ cell hyperplasia. The significant correlation between the surface areas of the antra and the corrected $G$ cell counts per $\mathrm{mm}$ may be important for several reasons. First, $\mathrm{G}$ cell numbers can be assessed by counts of $G$ cells from representative (six to eight) antral biopsies in patients, even though the area of the antrum cannot be determined. Secondly, the same trophic factors, perhaps the vagal stimuli, may be responsible for stimulating and maintaining both the size of the area containing $G$ cells and the density of the cells per unit area.

G CELl POPULATION AND DUODENAL ULCER Cowley et al. (1973a) compared hypoglycaemiastimulated gastrin release in patients with duodenal ulcer and in normal subjects. They concluded that the patients had an increased functional $\mathrm{G}$ cell mass, resulting from an increase in either the number of $G$ cells, or the output of gastrin per cell. Our present studies suggest that $G$ cell populations may be increased in the antra of some patients with duodenal ulcer. Creutzfeldt et al. (1976) found an increased G cell count per unit area in only three of 58 patients with duodenal ulcer, and an increased antral gastrin concentration in 12 of 38 , but they did not measure total $\mathrm{G}$ cell population. However, the marked differences in basal and stimulated plasma gastrin (and basal and stimulated acid output) both within the duodenal ulcer group and between patients with duodenal ulcer and normal subjects, are unlikely to be due to differences in numbers of $G$ cells in the antra alone, and other factors responsible may be differences in other stimulatory and inhibitory hormones (Bloom and Polak, 1977; Pearse et al. 1977).

We did not measure the amount of gastrin in the antrum. Creutzfeldt et al. (1976) found no correlation between the concentration of immunoreactive gastrin in antral biopsies and the number of $G$ cells perunit area. It is therefore not surprising that they found no correlation between, on the one hand, antral gastrin concentration and, on the other, basal acid output and peak acid output, fasting gastrin and meal-stimulated gastrin. Malmstrom and Stadil (1975) found no correlation between antral gastrin concentration and peak acid output after pentagastrin, while Malmstrom et al. (1976) found an inverse relationship.

G CELLS, ACID AND GASTRIN

The early studies of basal acid output and basal plasma gastrin in patients with duodenal ulcer showed either an inverse correlation (Trudeau and McGuigan, 1971; Moore and Wolfe, 1973) or no significant relationship (Cowley et al., 1971, Wesdorp and Fisher, 1974; Creutzfeldt et al., 1976). In the present study there was a significant direct correlation (rho $=0.55, \mathrm{P}<0.02$ ) between basal acid output and basal plasma gastrin as in our larger series (Royston et al., 1975) and in some other reports (Kronborg et al., 1975; Petersen et al., 1975). We speculate that in patients with duodenal ulcer, high basal acid output and basal gastrin levels may be due to increased stimulation, again perhaps vagal, which may also be responsible for the high peak acid output and $G$ cell populations of some of these patients.

We found a significant correlation between basal 
plasma gastrin and $\mathrm{G}$ cell density, even though a proportion of the fasting gastrin is derived from the duodenum, and is not altered by antrectomy. The insulin bicarbonate test, which we used to stimulate gastrin release, also releases extra-gastric gastrin, since, after complete truncal vagotomy and antrectomy (with Billroth I anastomosis), an appreciable amount of gastrin is still released 10 days and three months after operation (Royston et al., 1975). Thus it is not surprising that the correlations between insulin-stimulated release of gastrin and $G$ cell density or population were not significant at the $5 \%$ level, and that Kronborg et al. (1973) found no significant correlation between antral size and insulin-stimulated plasma gastrin. The correlations, of border line significance, found between basal and peak acid output after pentagastrin on the one hand and $G$ cell population on the other, are of particular theoretical importance, when considered with other, significant, correlations-namely, those between (1) antral size and insulin-stimulated acid (Kronborg and Madsen, 1972), (2) insulin-stimulated gastrin and acid (Kronborg et al., 1973), and (3) meal-stimulated gastrin and maximum acid output (Gedde-Dahl, 1975). These correlations are compatible with the hypothesis that, in patients with duodenal ulcer, acid and gastrin secretion are interrelated and are both related to parietal cell mass and to $\mathrm{G}$ cell mass.

\section{HYPERGASTRINAEMIA AND G CELL}

HY PER PLASIA

Ganguli et al. (1974) suggested that there might be two groups of patients with duodenal ulcer, one with high plasma gastrin responses to an Oxo meal and an increased number of antral $G$ cells, the other with lower plasma gastrin responses and fewer antral G cells. In this study, where total cell populations were estimated, we have seen no indication of the existence of two subgroups in our 15 patients. Although the $G$ cell counts have a very wide range. they appeared in this small series to represent a single homogeneous population.

We have been able to study only two patients with recurrent duodenal ulcer. (Two other antral studies were abandoned because of uneven distribution of $\mathbf{G}$ cells.) The one with incomplete vagotomy had a normal basal gastrin level $(10 \mathrm{pmol} / \mathrm{l})$, and a low $\mathrm{G}$ cell count ( 5.7 million). In the second patient (with apparent complete vagotomy), although the fasting gastrin level was normal $(16 \mathrm{pmol} / \mathrm{l})$ the total $\mathrm{G}$ cell population ( 45.8 million) was higher than that in any of the patients with duodenal ulcer and higher than in one of the patients with suspected ZollingerEllison syndrome. It seems likely that his recurrent ulceration was due to $G$ cell hyperplasia.

Both of our patients with hypergastrinaemia and duodenal ulcer had normal antral areas, but both had very high $G$ cell densities. They had either moderate ( 29 million) or very marked ( 56 million) G cell hyperplasia of their resected antra and both have remained symptom free with normal or near normal plasma gastrin after gastrectomy. These two clearly had duodenal ulcer, hypergastrinaemia, and $G$ cell hyperplasia. Such patients are rare, and probably represent not more than one in 100 of those with duodenal ulcer. It is therefore not yet possible to decide whether $G$ cell hyperplasia is merely the extreme of the normal continum of the numbers of $G$ cells in the antrum, or a separate entity outside the normal range of $\mathrm{G}$ cell population. Moreover, many of the patients reported with antral $G$ cell hyperplasia (and one of our two) have been investigated and diagnosed only after vagotomy, which by itself raises plasma gastrin (Malmstrom et al., 1977).

We are grateful to Professor John Wyllie and $\mathrm{Mr}$ Victor Brooks for sending us the stomachs of patients with hypergastrinaemia and allowing us to incorporate their data. Sir Rodney Smith kindly provided the antra of three of the control patients. We thank the Medical Research Council for their support of the project.

\section{References}

Abercrombie, M. (1946). Estimation of nuclear population from microtome sections. Anatomical Record, 94, 239-247.

Bloom, S. R., and Polak, J. M. (1977). The new peptide hormones of the gut. In Progress in Gastroenterology vol. 3. Edited by G. B. J. Glass. Grune and Stratton: New York.

Bussolati, G., and Pearse, A. G. E. (1970). Immunofluorescent localization of the gastrin-secreting $\mathbf{G}$ cells in the pyloric antrum of the pig. Histochemie, 21, 1-4.

Capper, W. M., Butler, T. J., Buckler, K. G., and Hallett, C. P. (1966). Variation in size of the gastric antrum: measurement of alkaline area associated with ulceration and pyloric stenosis. Annals of Surgery, 163, 281-290.

Card, W. I., and Marks, I. N. (1960). The relationship between the acid output of the stomach following 'maximal' histamine stimulation and the parietal cell mass. Clinical Science, 19, 147-163.

Coons, A. H., Leduc, E. H., and Connolly, J. M. (1955). Studies on antibody production. 1. A method for the histochemical demonstration of specific antibody and its application to a study of the hyperimmune rabbit. Journal of Experimental Medicine, 102, 49-60.

Cowley, D. J., Baron, J. H., Hansky, J., and Korman, M. G. (1973a). The effect of insulin hypoglycaemia on serum gastrin and gastric acid in normal subjects and patients with duodenal ulcer. British Journal of Surgery, 60, 438443.

Cowley, D. J., Dymock, I. W., Boyes, B. E., Wilson, R. Y., Stagg, B. H., Lewis, M. R., Polak, J. M., and Pearse, A. G. E. (1973b). Zollinger-Ellison syndrome type 1: Clinical and pathological correlations in a case. Gut, 14, 25-29.

Cowley, D. J., Ganguli, P. C., Polak, J. M., Elder, J. B., and Pearse, A. G. E. (1975). The $G$ cell population of the pyloric antrum of the cat. Digestion, 12, 25-31. 
Cox, A. J., Jr, and Barnes, V. R. (1945). Experimental hyperplasia of the stomach mucosa. Proceedings of the Society for Experimental Biology and Medicine, 60, 118-120.

Creutzfeldt, W., Arnold, R., Creutzfeldt, C., Feurle, C., and Ketterer, H. (1971). Gastrin and G-cells in the antral mucosa of patients with pernicious anaemia, acromegaly and hyperparathyroidism and in a Zollinger-Ellison tumour of the pancreas. European Journal of Clinical Investigation, 1, 461-479.

Creutzfeldt, W., Arnold, R., Creutzfeldt, C., and Track, N. S. (1976). Mucosal gastrin concentration, molecular forms of gastrin, number and ultrastructure of G-cells in patients with duodenal ulcer. Gut, 17, 745-754.

Ganguli, P. C., Polak, J. M., Pearse, A. G. E., Elder, J. B., and Hegarty, M. (1974). Antral-gastrin cell hyperplasia in peptic ulcer disease. Lancet, 1, 583-586.

Gedde-Dahl, D. (1975). Serum gastrin response to food stimulation and gastric acid secretion in male patients with duodenal ulcer. Scandinavian Journal of Gastroenterology, 10, 187-191.

Hedenstedt, S., Adner, M., Lindgren, A., Lundquist, G., and Robertsson, B. (1967). Antrectomy after staining with congo red and transillumination. (Moe's best) Acta Chirurgica Scandinavica, 133, 539-543.

Kronborg, O., and Madsen, P. (1972). A comparison of gastric acid secretions after highly selective vagotomy without drainage and selective vagotomy with a pyloroplasty. Scandinavian Journal of Gastroenterology, 7, 615621.

Kronborg, O., Stadil, F., Rehfeld, J., and Christiansen, P. M. (1973). Relationship between serum gastrin concentrations and gastric acid secretion in duodenal ulcer patients before and after selective and highly selective vagotomy. Scandinavian Journal of Gastroenterology, 8, 491-496.

McGuigan, J. E. (1968). Gastric mucosal intracellular localization of gastrin by immunofluoresence. Gastroenterology, 55, 315-327.

Malmstrom, J., and Stadil, F. (1975). Measurement of immunoreactive gastrin in gastric mucosa. Scandinavian Journal of Gastroenterology, 10, 433-439.

Malmstrom, J., Stadil, F., and Christensen, K. C. (1977). Effect of truncal vagotomy on gastroduodenal content of gastrin. British Journal of Surgery, 64, 34-38.

Malmstrom, J., Stadil, F., and Rehfeld, J. F. (1976). Gastrins in tissue: concentration and component pattern in gastric, duodenal, and jejunal mucosa of normal human subjects and patients with duodenal ulcer. Gastroenterology, 70, 697-703.

Moore, J. G., and Wolfe, M. (1973). The relation of plasma gastrin to the circadian rhythm of gastric acid secretion in man. Digestion, 9, 97-105.

Pearse, A. G. E., Polak, J. M., and Bloom, S. R. (1977). The newer gut hormones: cellular sources, physiology, pathology and clinical aspects. Gastroenterology, 72, 746-761.
Peterson, H., Schrumpf, E., and Myren, J. (1975). Fasting serum gastrin and basal gastric acid secretion. Scandinavian Journal of Gastroenterology, 10, 721-724.

Polak, J. M., Bussolati, G., and Pearse, A. G. E. (1971). Cytochemical, immunofluorescence and ultra-structural investigations on the antral G-cells in hyperparathyroidism. Virchows Archiv, Abt. B. Zellpathologie, 9, 187-197.

Polak, J. M., Coulling, I., Doe, W., and Pearse, A. G. E. (1971). The G cells in pernicious anaemia. Gut 12, 319-323.

Polak, J. M., Hoffbrand, A. V., Reed, P. I., Bloom, S., and Pearse, A. G. E. (1973). Qualitative and quantitative studies of antral and fundic $G$ cells in pernicious anaemia. Scandinavian Journal of Gastroenterology, 8, 361-367.

Polak, J. M., Stagg, B., and Pearse, A. G. E. (1972). Two types of Zollinger-Ellison syndrome: immunofluorescent, cytochemical and ultra-structural studies of the antral and pancreatic gastrin cells in different clinical states. Gut, 13, 501-512.

Reid, N. C. R. W., Hackett, R. M., and Welbourn, R. B. (1961). The influence of cortisone on the parietal cell population of the stomach in the dog. Gut, 2, 119-122.

Royston, C. M. S., Cooke, W. M., Russell, R. C. G., Bloom, S. R., and Spencer, J. (1975). Plasma gastrin after proximal gastric vagotomy and vagotomy and antrectomy (Abstract). British Journal of Surgery, 62, 664.

Rubin, W. (1969). Proliferation of endocrine-like (enterochromaffin) cells in atrophic gastric mucosa. Gastroenterology, 57, 641-648.

Russell, R. C. G., Bloom, S. R., Fielding, L. P., and Bryant, M. G. (1976). Current problems in the measurement of gastrin release. A reproducible measure of physiological gastrin release. Postgraduate Medical Journal, 52, 645-650.

Solcia, E., Vassallo, G., and Sampietro, R. (1967). Endocrine cells in the antro-pyloric mucosa of the stomach. Zeitschrift für Zellforschung und mikroskopische Anatomie, 81, 474486.

Solcia, E., Capella, C., and Vassallo, G. (1970). Endocrine cells of the stomach and pancreas in states of gastric hypersecretion. Rendiconti di Gastroenterologia, 2, 147-158.

Stave, R., and Brandtzaeg, P. (1976). Immunohistochemical investigation of gastrin-producing cells ( $G$ cells). The distribution of $\mathbf{G}$ cells in resected human stomachs. Sandinavian Journal of Gastroenterology, 11, 705-712.

Trudeau, W. L., and McGuigan, J. E. (1971). Relations between serum gastrin levels and rates of gastric hydrochloric acid secretion. New England Journal of Medicine, 284, 408-412.

Wesdrop, R. I. C., and Fischer, J. E. (1974). Plasma-gastrin and acid secretion in patients with peptic ulceration. Lancet, 2, 857-860.

Willems, G., Nyst, M., Delincé, P., and De Graef, J. (1976). Direct method for estimating the total gastrin cell number in the stomach of rats. Gastroenterology, 71, 533-536. 